\title{
Effect of aerobic pretreatment of waste on the rate of anaerobic treatment processes
}

\author{
Monika Suchowska-Kisielewicz • Andrzej Jedrczak • \\ Zofia Sadecka $\cdot$ Sylwia Myszograj
}

Received: 24 May 2012/ Accepted: 5 November 2012/Published online: 21 November 2012

(C) The Author(s) 2012. This article is published with open access at Springerlink.com

\begin{abstract}
The efficiency of waste degradation can be expressed by the rate of waste decomposition in individual phases. This article presents the durations of degradation phases of pretreated and untreated waste stabilized in anaerobic laboratory reactors. In this investigation, the quantities of organic and nitrogen contaminants emitted from the waste during the study are presented. The study confirmed the beneficial effects of aerobic pretreatment of waste before landfilling on reducing the duration of hydrolysis and acid phases, and speeding up the start of the stable methane phase. In the pretreated waste reactor, the stable methane phase began about 19 weeks earlier than in the untreated waste. The total amounts of contaminants removed from the aerobic pretreatment waste were lower than from untreated waste, with values of COD, TOC, $\mathrm{BOD}_{5}$, and VFA corresponding to $21,18,6$, and $23 \%$, respectively, and values of TKN and $\mathrm{NH}_{4}$ of 7 and $50 \%$, respectively.
\end{abstract}

Keywords Landfills - Leachate - Municipal solid waste . Mechanical-biological treatment $\cdot$ Reduction of emission potential

\section{Introduction}

One of the major tasks of municipal waste management in the countries of the European Union is the systematic

M. Suchowska-Kisielewicz ( $₫) \cdot$ A. Jedrczak · Z. Sadecka · S. Myszograj

The Institute of Environmental Engineering, University of Zielona Gora, Licealna 9, 65-417 Zielona Gora, Poland e-mail: m.suchowska-kisielewicz@iis.uz.zgora.pl reduction of waste that is removed and transported to landfills. This refers particularly to biodegradable waste [1]. The presence of such waste influences the amount of emitted pollution via leachates and biogases into the environment. Poland adopted the landfill waste reduction targets of $25 \%$ by 2010 , of $50 \%$ by 2013 , and $65 \%$ by 2020 , in relation to the amount of landfill waste in 1995 [2]. One of the methods employed to decrease the amount of waste is mechanical-biological treatment (MBT) of the waste, before it is stored. The method has been recommended in The National Waste Management Plan 2010 as being useful for regions with populations of between 150,000 and 300,000 people. Mechanical-biological treatment (MBT) is a technology which consists of the use of the mechanical sorting of waste associated with the use of the biological stabilization of the remainder after sorting biodegradable waste. The mechanical sorting stage can be placed at the beginning of MBT (biostabilization) or after the biological process (biodrying).

In biostabilization technologies, the waste is subjected to aerobic or anaerobic-aerobic stabilization in order to reduce its susceptibility to biodegradation. Stabilized waste is primarily suited for landfill, but can also be used on nonagricultural soil and for the reclamation of land for construction or burned.

The aim of biostabilization is to achieve the highest degree of organic waste stabilization in order to reduce emissions from stabilized waste deposited in landfills. MBT also allows an increase in the recovery of recyclable materials and reduces the mass of waste deposited [3-6]. The degree of waste biostabilization depends on a number of factors: the waste morphological composition (the percentage of organic biodegradable substance), the type of method utilized, the conditions of the biological stabilization process, and its duration [7-10]. 
In developing countries, the recommended method of biological waste stabilization before landfilling is aerobic decomposition, which requires less investment and operating expenditures in comparison to anaerobic processes [11].

The literature data indicate that, under optimal aerobic stabilization conditions, a reduction of up to $90 \%$ of the content of organic substances can be achieved, which corresponds to a reduction in the landfill gas emission of up to as much as $15-20 \mathrm{~m}^{3} / \mathrm{Mg}$ of waste and in nitrogen of 80-90 \% in relation to emissions from untreated waste [12, 13]. An additional benefit resulting from using aerobic biostabilization is a reduction in the time of pollutant emissions, due to faster development of the stable methane conditions in landfills [3, 12, 14, 15].

Biological processes occurring in the landfill can be divided into phases. Each phase has its own environmental requirements and substrate, and ends with specific final products. Each phase is distinguished on the basis of the physical-chemical composition of the leachate, as well as the quantity and quality of biogas $[16,17]$. According to various scientific sources, the waste decomposition process may have three [18], four [16, 19], or five stages [20, 21]. It is frequently divided into four phases:

- Phase I, hydrolysis, characterized by high concentrations of organic substances in the leachate, aerobic conditions in the landfill, and a high content of readily biodegradable organic materials in the waste. The final products of hydrolysis are monosaccharides, amino acids, long-chain organic acids, and glycerol, which are substrates for the acid phase;

- Phase II, acidic, also characterized by high levels of organic substances in the leachate, intensive production of short-chain organic acids, a decrease in pH (5.5-6.5), and methane production at a level that is not detectable;

- Phase III, unstable methane, characterized by increased $\mathrm{pH}$, a decrease in redox potential to negative values, a decrease of volatile fatty acids concentrations and organic substances in leachate, a reduction in sulfates to sulfites, and intensive production of methane;

- Phase IV, methane stable, characterized by relatively constant, low concentrations of organic materials in the leachate, a growth of redox potential, a decrease of biogas production, and a methane content in biogas at a relatively constant, high level—around 60-70\%.

The duration of each distinguished phase depends on the rates of the course of hydrolysis and acid and methane phases, which depend on the rate of substrates production in the previous phases.

This article presents the durations of the phases of the degradation of pretreated and untreated waste stabilized in anaerobic laboratory reactors and the total load of organic pollutants and forms of nitrogen emitted from the waste during the study.

\section{Materials and methods}

Research material

The research was conducted on municipal solid waste (MSW, unprocessed biologically) and biologically stabilized (ST) waste, collected from an apartment block housing with central heating, in Zielona Góra, Poland. Biological processing was conducted in the Municipal Waste Composting Plant in Zielona Góra. The biological line installation consists of four open oxygen chambers made of reinforced concrete. Every 7-10 days, the waste is moved to another chamber. The overall waste stabilization time is approximately 5 weeks. The waste is aerated by removing gasses from the bottom of the chambers via suction.

A sample of MSW was prepared from samples weighing about $25 \mathrm{~kg}$ selected randomly from 10 vehicles delivering waste to the composting bunkers. Samples of pretreated waste were collected from 10 randomly selected batches of composted waste. Laboratory samples of weights of over $10 \mathrm{~kg}$ were obtained by reducing the general sample by averaging and using the method of quartering.

The waste was subjected to chemical analysis and composition investigation.

The composition of the waste was determined in the fraction $>10 \mathrm{~mm}$. The waste was separated into the following components: kitchen and garden waste, paper and cardboard, glass, plastics, textiles, composite packaging, wood, metals, and mineral wastes. The composition of waste was presented as the share of the respective fractions in the total mass of waste, in $\%(\mathrm{~m} / \mathrm{m})$. The scope of chemical analysis included the following indications: moisture content, volatile substances (ignition loss at $500{ }^{\circ} \mathrm{C}$ ), and organic carbon.

All indications were made according to Standard Methods [American Public Health Association (APHA), 1995] and Polish Standards.

\section{Research area}

The study of the emission of pollutants from untreated and biologically treated waste was performed using a laboratory scale in two reactors made of PVC pipes with a diameter of $0.15 \mathrm{~m}$ and height $1.30 \mathrm{~m}$. In the bottom of each reactor, an outlet was installed (pipe with a valve) for the draining of effluents. In the top of the reactors, an outlet was installed for the removal of the biogas (Fig. 1), together with an inlet for the dosage of water to simulate 


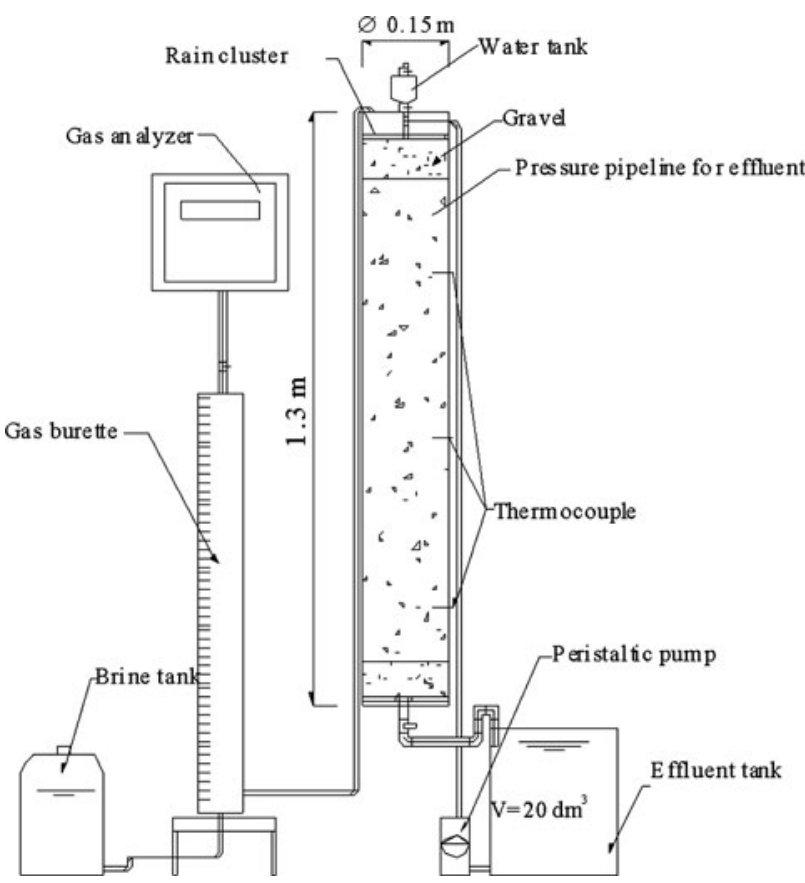

Fig. 1 Scheme of the bioreactor

rainfall. The leachate was stored in a tank with a capacity of $20 \mathrm{dm}^{3}$.

The gas outlet in the top cap of the reactor was connected by a flexible pipeline to a gas burette (cylinders with diameter $85 \mathrm{~mm}$ with scale). The burette was filled with saturated $\mathrm{NaCl}$ solution. A valve was placed at the top of the burette for the removal of the accumulated gas and the collection of samples for analysis. High concentrations of $\mathrm{NaCl}$ in the burette limited dissolution of the biogas components. The second outlet in the top cap of the reactor was combined with a recycled water storage tank to simulate rainfall. At the bottom of each reactor was placed a $0.15-\mathrm{m}$ gravel layer. Thermocouples were mounted in the walls of the reactors. In each reactor, $10 \mathrm{~kg}$ of waste shredded to a grain size of $<40 \mathrm{~mm}$ and thoroughly mixed were placed. Waste layers with a height of $0.15-1.20 \mathrm{~m}$ were placed in the reactors and were thickened manually to a density of $565 \mathrm{~kg} / \mathrm{m}^{3}$. The surface of the waste was covered with a $0.05-\mathrm{m}$ layer of gravel with a diameter of grain from 10 to $20 \mathrm{~mm}$.

\section{Process operation}

The process was started by dosing water to each reactor in the amount of $1 \mathrm{dm}^{3} /$ day in order to saturate the waste with water. The water was dosed to the top of the reactors to start the leachate production. Then, the introduction of a daily dosage of water simulating precipitation was started. During the 51 weeks of the study, water was introduced into the reactors at a volume corresponding to the amount of precipitation recorded in Zielona Góra in a period of monitoring of 2.5 years (from June 2003 to December 2005). The volume of water $\left(\mathrm{dm}^{3}\right)$ introduced into the reactor in relation to the weight of landfilled waste $(\mathrm{kg})$ was $\mathrm{L} / \mathrm{S}=2.5$. The amounts of produced biogas and leachate were monitored daily. The chemical composition of leachate $\left(\mathrm{pH}, \mathrm{COD}, \mathrm{TOC}, \mathrm{VFA}, \mathrm{BOD}_{5}, \mathrm{TKN}\right.$ and $\left.\mathrm{NH}_{4}\right)$ and biogas $\left(\mathrm{CH}_{4}, \mathrm{CO}_{2}, \mathrm{O}_{2}\right)$ were tested once a week.

\section{Results}

Chemical properties and composition of waste

The chemical properties and composition of the untreated and pretreated waste are shown in Table 1.

The municipal waste was characterized by a higher moisture and organic carbon content than the pretreated waste. The total organic carbon content in the aerobic treated waste was lower by $29 \%$.

The dominant components in the untreated waste were kitchen and garden waste $(42.5 \%)$ and paper and cardboard $(17.5 \%)$. The share of these fractions in the MSW compared to the ST was higher by approximately 30 and $17.4 \%$, respectively. The share of the other components was lower than in the ST: glass $27.5 \%$, plastic $31.0 \%$, textile $16.0 \%$, packing material $44.0 \%$, metal $18.7 \%$.

Amount and composition of biogas and leachate

Figure 2 shows the amount of dosage of water to the reactors and the leachate removed from the untreated

Table 1 The chemical properties and composition of waste

\begin{tabular}{lcc}
\hline Parameters & MSW & ST \\
\hline Waste properties & & \\
Moisture content, \% & 40.2 & 34.5 \\
Volatile solid, \% of dry matter & 58.5 & 52.2 \\
Organic carbon, kg/kg of dry matter & 0.38 & 0.27 \\
Composition of the waste (average percentage wet & weight) & \\
Food and vegetable leftovers & 42.5 & 32.6 \\
Paper and cardboard & 17.5 & 14.9 \\
Glass & 9.8 & 12.5 \\
Plastic & 13.5 & 17.7 \\
Textile & 2.5 & 2.9 \\
Packing material (miscellaneous composition) & 2.5 & 3.6 \\
Wood & 0.1 & 0.1 \\
Metal & 1.6 & 1.9 \\
Mineral waste & 10.0 & 13.8 \\
Overall & 100 & 100 \\
\hline
\end{tabular}


Fig. 2 The average weekly volume of water dosed to the reactors and leachate removed from untreated waste as well as biologically treated waste

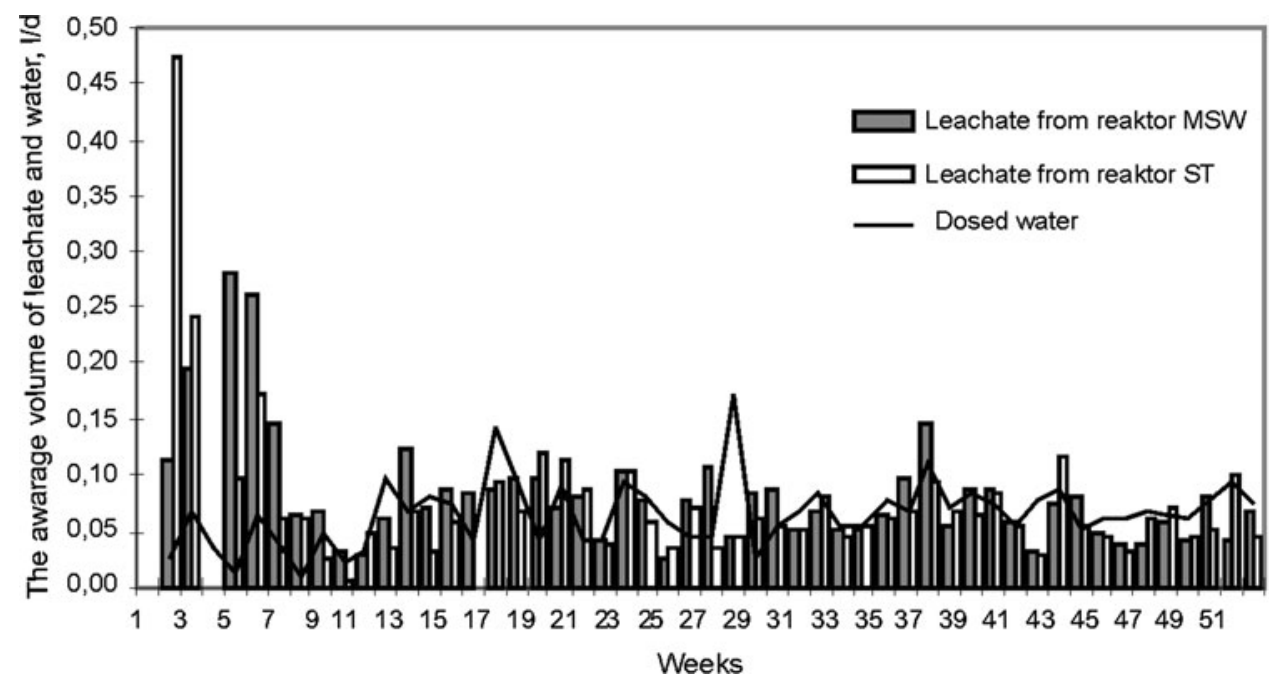

(MSW reactor) and the biologically pretreated waste (ST reactor). The quantities of leachate from the MSW and ST reactors in the initial study period (up to 7 weeks) were significantly higher than the amount of dosage of water: in the treated waste, it was 5 times higher, and in the untreated waste, it was 4 times higher. In the remaining period, the volume of leachate and the dosage of water differed slightly or were significantly lower. The total volume of leachate from the MSW reactor was similar to the volume of water dosage (about $3.6 \%$ higher), while in the ST reactor, it was lower by about $11 \%$.

In Figs. 3 and 4, the course of the characteristic phases of decomposition are shown; I, hydrolysis; II, acid phase; III, unstable methane phase; IV, stable methane phase; all determined based on changes in the leachate, that is, the concentration of $\mathrm{COD}, \mathrm{VFA}$, and $\mathrm{pH}$, the methane production, and the share of the methane in the biogas in reactors MSW and ST.

In the various phases of decomposition, the concentrations of COD and VFA in the leachate removed from ST were higher than in the leachate from MSW in the phases of acid and methane fermentation, while in the phase of stable methane fermentation, it was significantly lower (Table 2).

The average concentrations of COD and VFA in the leachate removed from the MSW reactor in the first three phases were lower than in the leachate taken from the ST reactor:

- Phase I: COD $25 \%$, VFA $28 \%$,

- Phase II: COD $36 \%$, VFA $33 \%$

- Phase III: COD $31 \%$, VFA $16 \%$,
Fig. 3 Changes in the chemical composition of leachate and changes in the average concentrations and average methane production in the MSW reactor

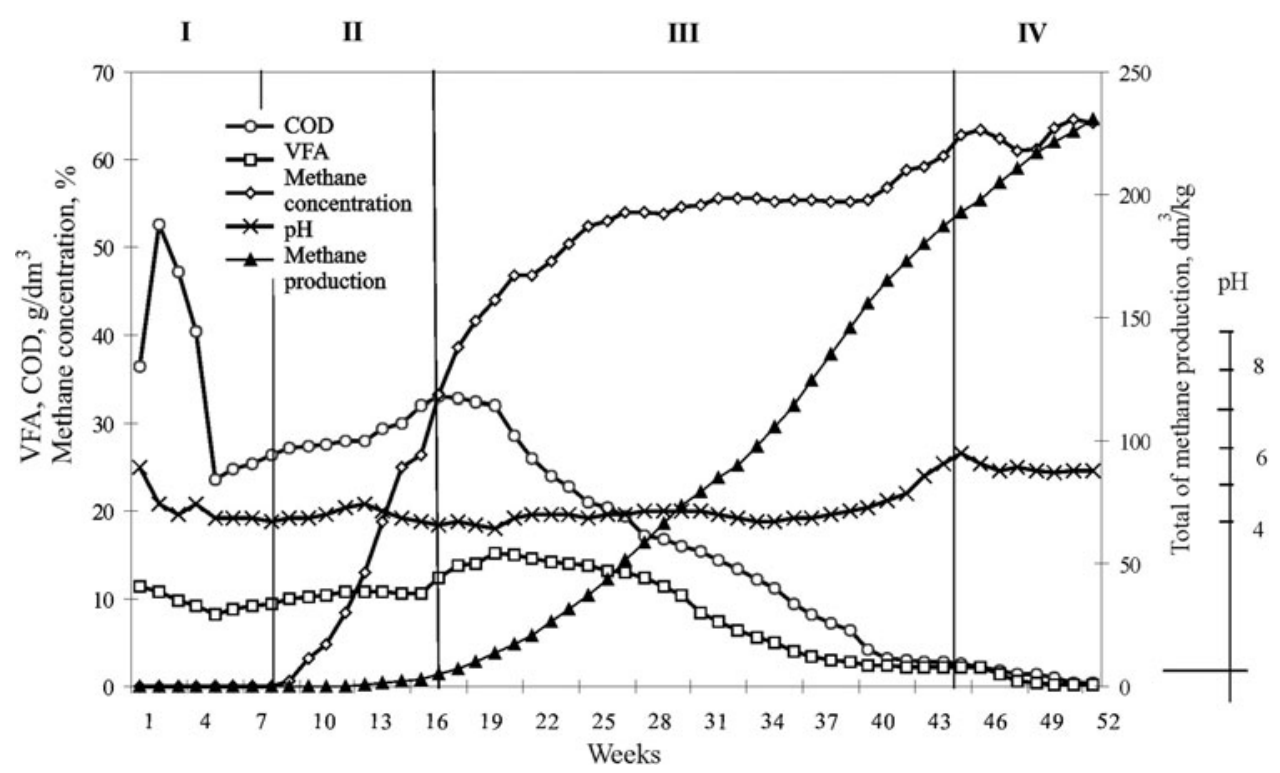


Fig. 4 Changes in the chemical composition of leachate and changes in the average concentrations and average methane production in the ST reactor

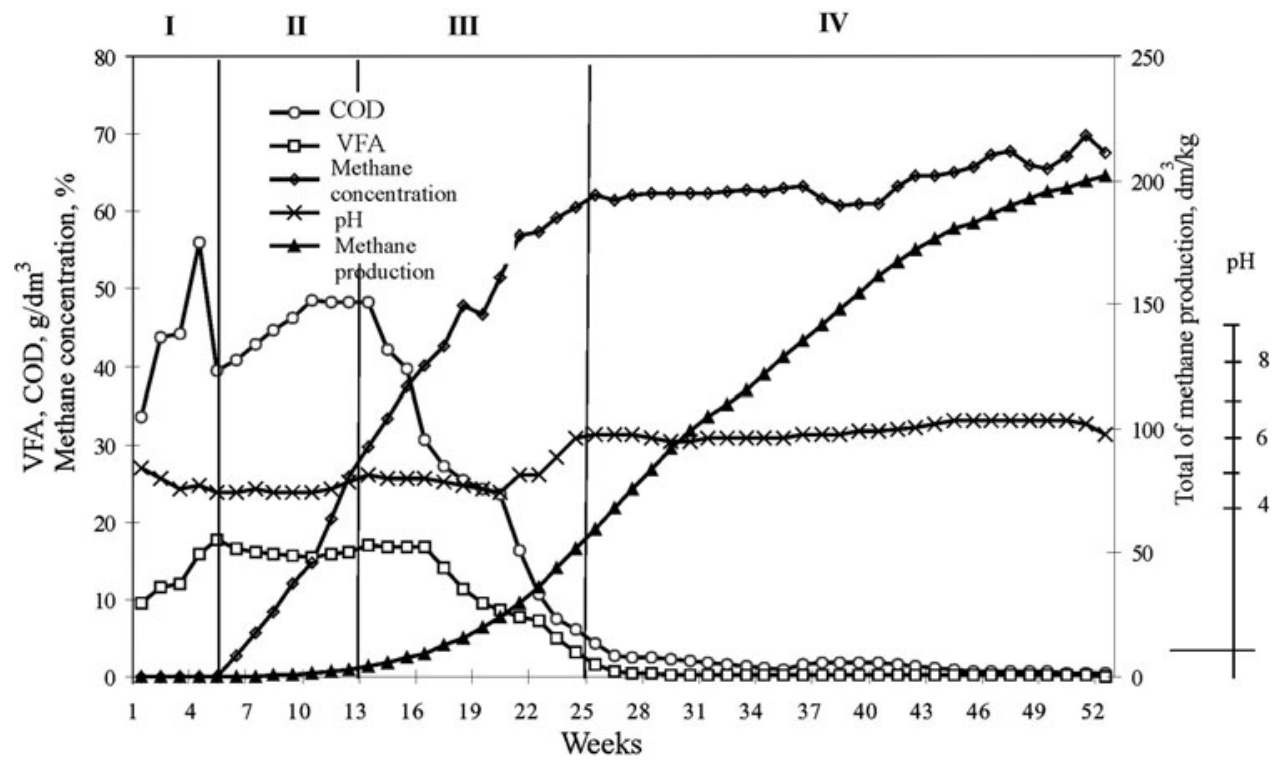

Table 2 Average concentrations of COD, VFA, $\mathrm{CH}_{4}$, and $\mathrm{pH}$ ranges, and the average production of methane in the various phases of the MSW and $\mathrm{ST}$ reactor

\begin{tabular}{|c|c|c|c|c|c|c|c|c|c|c|}
\hline \multirow{2}{*}{$\begin{array}{l}\text { Reactor } \\
\text { Phase }\end{array}$} & \multicolumn{4}{|l|}{ MSW } & \multicolumn{4}{|l|}{ ST } & \multirow{2}{*}{$\frac{\text { MSW }}{\text { I-IV }}$} & \multirow{2}{*}{$\frac{\text { ST }}{\text { I-IV }}$} \\
\hline & I & II & III & IV & I & II & III & IV & & \\
\hline $\mathrm{COD}, \mathrm{g} / \mathrm{dm}^{3}$ & 34.6 & 29.2 & 16.3 & 1.6 & 43.3 & 45.9 & 23.5 & 1.3 & 18.7 & 16.9 \\
\hline VFA, $\mathrm{g} / \mathrm{dm}^{3}$ & 9.6 & 10.72 & 8.7 & 1.1 & 13.4 & 16.1 & 10.4 & 0.3 & 7.9 & 6.2 \\
\hline $\mathrm{pH}$ & $4.8-6.4$ & $4.7-5.3$ & $4.6-6.5$ & $6.2-6.8$ & $5.3-6.0$ & $5.3-5.8$ & $5.3-7,0$ & $6.8-7.4$ & $4.6-6.8$ & $5.3-7.4$ \\
\hline $\mathrm{CH}_{4}, \%$ & 0 & 14.9 & 52.1 & 62.6 & 0 & 10.6 & 48.1 & 63.8 & 39.7 & 46.9 \\
\hline $\mathrm{CH}_{4}$ production, $\mathrm{dm}^{3} / \mathrm{kg}$ & 0 & 4.7 & 184.3 & 50.7 & 0 & 4.3 & 56.2 & 150.6 & 230.4 & 202.0 \\
\hline
\end{tabular}

but they were higher in the fourth phase:

- $\quad$ Phase IV: COD $19 \%$, VFA $72 \%$.

The average values of methane concentration in the biogas in the MSW and ST reactors, in each particular phase, had similar values, but the average concentration of methane in the ST reactor, determined for the whole study period, was higher by $15 \%$.

The production of methane in the MSW reactor in the acid and the methane phases was higher sequentially by 9 and $70 \%$, and in the methane stable phase, it was lower by $66 \%$.

\section{Discussion}

The degradation of the waste, as expected, took place faster in the reactor with the waste after initial aerobic stabilization. Unstable and stable methane fermentation began in the ST reactor at weeks 13 and 25 of the study, while in the reactor of unprocessed waste, it began at weeks 17 and 44 (Figs. 3 and 4). As presented in Table 2, changes in the chemical composition of the leachate from the biologically treated and untreated waste confirmed that the initial aerobic treatment of waste before storage helps to reduce the emissions of concentrations of organic pollutants in leachate and methane production, as well as to establish stable methane conditions more quickly [14].

The studies showed that the average concentrations of COD and VFA, during the phases of hydrolysis, acid, and unstable methane fermentation, in the leachate from aerobic treated waste were higher than in the leachate from untreated waste, and in the stable methane fermentation phase, they were significantly lower. It was also found that the unstable phase of fermentation, characterized by an intense decrease in organic matter and increase in methane production, began in the ST reactor about 4 weeks earlier than in the MSW reactor. This confirms that the aerobic treatment of waste prior to its anaerobic stabilization accelerates the growth of methane bacteria. Faster establishment of the conditions of methane in the reactor of waste after pretreatment was the result of the removal of organic matter susceptible to biodegradation from waste during aerobic decomposition prior to anaerobic stabilization. On the other hand, the high methane production observed in the stable phase of methane fermentation in the 
ST reactor indicates a partial breakdown of the complex organic substances that are difficult to degrade, which remain after initial aerobic treatment. The dominant organic components in the waste are: cellulose $50 \%$, lignin $15 \%$, hemicellulose $10 \%$, protein $5 \%$, and starch, pectin, and other soluble sugars [14]. The main sources of carbon, used by methane microorganisms, are cellulose and hemicellulose, which are classified as materials that are difficult to degrade under anaerobic conditions. Aerobic processing of these complex organic substances prior to anaerobic decomposition leads to the degradation of these complex organic components to form easily available methane-producing microorganisms [22]. The increased activity of methane bacteria can be identified by a sharp decrease in the concentration of organic matter in leachate and the relatively high methane production [23]. Figure 5 shows the total loads of pollutants removed from the MSW and ST waste during the study. Initial aerobic waste treatment reduces the potential of the waste for the emission of contaminants that can be washed from it during landfilling. A significant effect of aerobic waste is to reduce the concentrations and loads of organic pollutants in
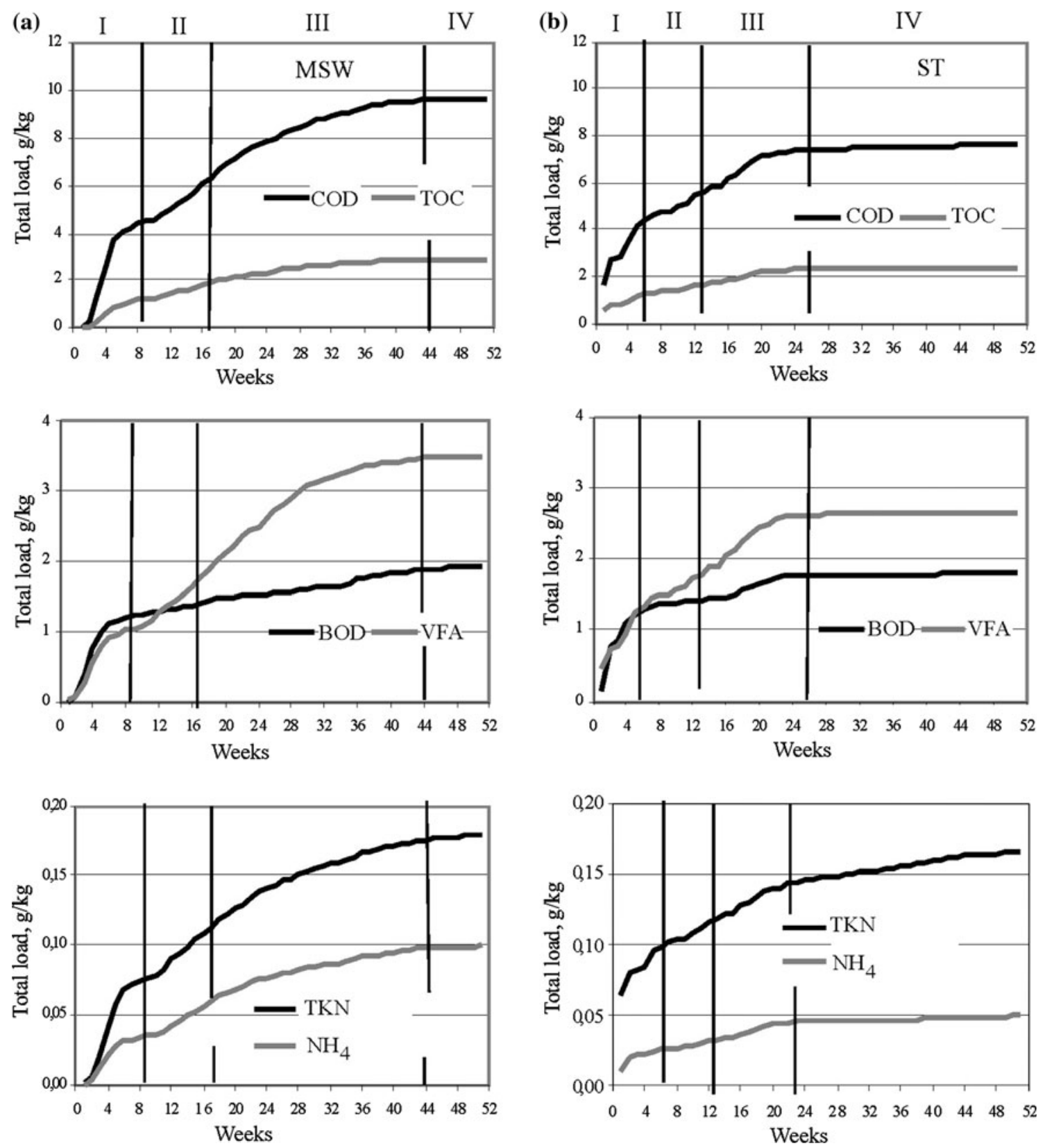

Fig. 5 The total loads of contaminants removed from the MSW and ST reactors 
leachate and the emissions of methane production from the waste after aerobic pretreatment (Figs. 3, 4, and 5). The average concentrations of COD and VFA in the leachate from aerobic pretreated waste and the total methane production determined in the whole study period were lower than in the untreated waste by, respectively, 9,22 , and $12 \%$ (Table 2).

The values of the loads of organic pollutants and nitrogen forms determined for the ST confirm that the initial aerobic waste treatment has an influence on the rate of leaching of contaminants from landfills ("flattening curves") and reduces the overall loads of pollutants leached from the waste. The total pollution load washed out over the study period from the ST reactor was lower than from the MSW reactor, respectively:

- COD, TOC, $\mathrm{BOD}_{5}$, and VFA: 21, 18, 6, and $23 \%$,

- Total nitrogen and ammonium: 7 and $50 \%$.

According to a study by Stegman [13], intensive waste composting (16-30 weeks) before disposal to the landfill reduces the emissions of organic pollutants and the production of biogas by 80-90\%, compared to the emission from untreated waste.

The reason for the low degree of reduction in pollutant emissions in leachate and methane production removed from aerobic pretreated waste obtained in the study was that the (5-week) period of aerobic pretreated waste stabilization was too short. In summary, based on the obtained results, it can be concluded that the initial stabilization of waste under aerobic conditions prior to storage significantly reduces the emission of organic pollutants in leachate and biogas. However, 5 weeks aeration of the waste is too short a period to implement the obligations under the Landfill Directive 1999/314/EC on waste landfill after 2013.

\section{Summary}

1. The studies confirmed that the aerobic pretreatment of waste before it is stabilized in anaerobic conditions leads to the faster establishment of stable conditions for methane production.

2. Five weeks of aerobic stabilization of municipal waste before landfilling is too short a time to reduce the emissions of organic pollutants in leachate and biogas from waste to a degree that guarantees fulfillment of the obligations under the Landfill Directive after 2013.

Open Access This article is distributed under the terms of the Creative Commons Attribution License which permits any use, distribution, and reproduction in any medium, provided the original author(s) and the source are credited.

\section{References}

1. Waste Management Act of 27 April 2001 (Dz.U.2001.62.628)

2. Council Directive 1999/31/EC of 26 April 1999 on the landfill of waste

3. Lornage R, Redon E, Lagier T, Hébé I, Carré J (2007) Performance of a low cost MBT prior to landfilling: study of the biological treatment of size reduced MSW without mechanical sorting. Waste Manag 27:1755-1764

4. Leikam K, Stegmann R (1995) The emission behavior of mechanically-biologically pretreated residual waste. Waste Reports Emissionsverhalten von Restmull, ABF-BOKU, Vienna, Austria

5. Rieger A, Bidlingmaier W (1995) The reactivity of mechanically-biologically pretreated residual waste. Waste Reports Emissionsverhalten von Restmull, ABF-BOKU, Vienna, Austria

6. Soyez K, Plickert S (2002) Mechanical-biological pre-treatment of waste: state of the art and potentials of biotechnology. Acta Biotechnol 22(3-4):271-284

7. Fricke K, Mümmich K, Ziehmann G, Turk T, Wallmann R (2001) Auswirkungen der artikelverordnung auf die MBA-und Deponietechnik, Bio- und Restabfallbehandlung

8. Schön M (1994) Verfahren zur Vergärung organischer Rückstände in der Abfallwirtschaft. Erich Schmidt Verlag, Berlin

9. Schroeder PR, Morgan JM, Wolski TM, Gibson AC (1983) The hydrologic evaluation of landfill performance (HELP) model using physical models, user's guide for version 1. U.S. Environmental Protection Agency, USA

10. Ketelsen K (2001) Umsetzung der Ablagerungsanforderungen im MBA- und deponiebetrieb, w: Bio und Restabfallbehandling V

11. Fricke K, Mümmich K, Ziehmann G, Turk T, Wallmann R (2001) Stand der Auswirkungen der Artikelverordnungen auf die MBAund Deponietechnik. In: Bio- und Restabfallbehandlung V, Wiemer, K. und M. Kern (Hrsg.) Witzenhausen-Institut, pp 559-590

12. Robinson HD, Knox K, Bone BD (2004) Improved definition of leachate source term from landfills. Phase 1: review of data from European landfills. Science Report P1-494/SR1. Environment Agency, September 2004. Available online at: http://cdn. environment-agency.gov.uk/scho0904bigd-e-e.pdf

13. Stegman R (1991) Vorteile der Restmüll-Aufbereitung zur Senkung der Gasemissionen von Deponien. In: Aufbereitung fester Siedlungsabfälle vor der Deponierung, Zentrum für Abfallforschung, Technical University of Braunschweig, pp 341-359

14. Bockreis A, Steinberg I (2005) Influence of mechanical-biological waste pre-treatment methods on the gas formation in landfills. Waste Manag 25:337-343

15. Rich C, Gronow J, Voulvoulis N (2008) The potential for aeration of MSW landfills to accelerate completion. Waste Manag 28: 1039-1048

16. Sanphoti N, Towprayoon S, Chaiprasert P, Nopharatana A (2006) The effects of leachate recirculation with supplemental water addition on methane production and waste decomposition in a simulated tropical landfill. J Environ Manag 81:27-35

17. Francois V, Feuillade G, Matejka G, Lagier T, Skhiri N (2007) Leachate recirculation effects on waste degradation: study on columns. Waste Manag 27:1259-1272

18. McBean EA, Rovers FA, Farquhar GJ (1995) Solid waste landfill engineering and design. Prentice Hall, Englewood Cliffs

19. Vavilin VA, Fernandez B, Palatsi J, Flotats X (2008) Hydrolysis kinetics in anaerobic degradation of particulate organic material: an overview. Waste Manag 28:939-951

20. Pohland FG, Ghosh S (1971) Developments in anaerobic stabilization of organic wastes - the two-phase concept. Environ Lett $1: 255-266$ 
21. Reinhart DR, Basel Al-Yousfi A (1996) The impact of leachate recirculation on municipal solid waste landfill operating characteristics. Waste Manag Res 14:337-346

22. Barlaz MA, Ham RK, Schaefer DM (1992) Microbial, chemical and methane production characteristics of anaerobically decomposed refuse with and without leachate recycling. Waste Manag Res 10:257-267

23. Erses AS, Onay TT, Yenigun O (2008) Comparison of aerobic and anaerobic degradation of municipal solid waste in bioreactor landfills. Bioresour Technol 99:5418-5426 